\title{
Prostacyclin signaling regulates circulating ghrelin during acute inflammation
}

\author{
Lisa D Madison ${ }^{1}$, Jarrad M Scarlett ${ }^{2}$, Peter Levasseur ${ }^{3}$, XinXia Zhu ${ }^{3}$, Kenneth Newcomb ${ }^{3}$, Ayesha Batra ${ }^{3}$, \\ Darren Bowe ${ }^{3}$ and Daniel L Marks ${ }^{1,2,3}$ \\ ${ }^{1}$ Department of Pediatrics and ${ }^{2}$ Neuroscience Graduate Program, Oregon Health and Science University, Portland, Oregon, USA \\ ${ }^{3}$ Center for the Study of Weight Regulation, Oregon Health and Science University, 3181 SW Sam Jackson Park Road, L 481, Portland, Oregon 97239, USA \\ (Correspondence should be addressed to D L Marks; Email: marksd@ohsu.edu)
}

\begin{abstract}
Ghrelin is an octanoylated 28 amino acid peptide predominantly secreted by the stomach, and has potent stimulatory effects on appetite. Several laboratories, including our own, have demonstrated that ghrelin levels fall in states of acute inflammation brought about by injection of bacterial lipopolysaccharide (LPS). We now demonstrate that the decrease in circulating ghrelin is not due to a decrease in ghrelin gene expression, but is instead likely to be due to an acute decrease in ghrelin secretion. Furthermore, we have found that the change in circulating ghrelin during acute inflammation required a prostaglandin second messenger, but did not require the synthesis of nitric oxide. Interestingly, i.v. injection of prostaglandin $\mathrm{E}_{2}$ failed to decrease circulating ghrelin levels, whereas prostacyclin decreased circulating ghrelin to a similar extent as did LPS. We also provide anatomical evidence for the mechanism of the regulation of
\end{abstract}

ghrelin by inflammation. We demonstrate that the type 1 interleukin-1 $\beta$ (IL-1 $\beta$ ) receptor is expressed within the gastric mucosa, but is not expressed by ghrelin cells. The prostacyclin receptor was also expressed in the gastric mucosa, and the majority of ghrelin-producing cells were found to co-express this receptor. Mice with genetic deletion of the type 1 IL-1 receptor do not suppress circulating ghrelin levels with LPS administration. Collectively, these data support a model in which the mechanism of inflammation induced decreases in ghrelin are due to the action of IL-1 $\beta$ on cells within the gastric mucosa that in turn produce prostacyclin as a second messenger. These data provide further support for the potential role of ghrelin as a therapeutic agent in acute and chronic inflammatory diseases.

Journal of Endocrinology (2008) 196, 263-273

\section{Introduction}

Health problems related to weight regulation are increasingly common in the United States and around the world. While obesity and its associated complications garner the most attention in the media, clinical problems at the opposite end of the spectrum, such as involuntary disease-associated weight loss or cachexia, are equally devastating. Cachexia is a state of profound malnutrition brought about by a synergistic combination of a dramatic decrease in appetite and an inappropriate increase in metabolism of both fat and lean body mass. The severity of cachexia in many illnesses is the primary determining factor in both quality of life and eventual mortality (Tisdale 1997, Larkin 1998); however, despite intense research efforts, disease-associated wasting remains poorly understood and there is currently no effective pharmacologic treatment. Much of the work on cachexia to date has focused on the hypothesis that interleukins (IL) and other cytokines released during inflammation and malignancy act on the central nervous system (CNS) to alter the release and function of a number of key neurotransmitters, thereby altering both appetite and metabolic rate (PlataSalaman 1989, 1999, Tisdale 1997, Inui 1999b). In addition to cytokines, a number of secreted hormones from the pancreas and gut have been shown to affect both short-term appetite and long-term body weight through central signals to the brainstem and hypothalamus. For example, Cowley et al. (2003) have clearly demonstrated that the orexigenic enteric hormone, ghrelin, exerts it actions, at least in part, by decreasing the activity of the hypothalamic melanocortin system.

Identified as an endogenous ligand for the growth hormone secretagogue receptor (GHS-1R; Kojima et al. 2001), ghrelin is an octanoylated 28 amino acid peptide predominantly secreted by the stomach. Serum levels of ghrelin are increased by fasting and ghrelin has potent effects on appetite, body weight, and fat utilization (Tschop et al. 2000, Cummings et al. 2001, Kojima et al. 2001). Ghrelin levels are markedly reduced with meal ingestion in both rodents and humans but rebound to baseline before the next meal and increase after an overnight fast (Tschop et al. 2000, 2001a, Cummings et al. 2001), suggesting a role in meal 
initiation. In rodents, this was demonstrated to be a nutrientspecific effect since a similar volume of saline infused into the stomach did not affect ghrelin levels (Tschop et al. 2000). Ghrelin may also play a longer-term role in energy homeostasis and body weight regulation. Fasting ghrelin levels have been shown to be inversely proportional to body weight (Tschop et al. 2001b) and to be higher in underweight subjects with anorexia nervosa when compared with controls (Ariyasu et al. 2001). Downregulation of ghrelin in obese subjects suggests an adaptive response to the obese state while a rise in levels in weight-reduced subjects is compatible with a 'counter-regulatory' role to restore fat depots.

In contrast to the upregulation of ghrelin with acute and prolonged fasting, decreases in food intake brought about by acute lipopolysaccharide (LPS)-induced inflammation do not result in increased circulating ghrelin in rodents (Basa et al. 2003, Hataya et al. 2003). LPS is a purified product found in the cell wall of gram-negative bacteria that reliably produces anorexia in experimental animals (Murray \& Murray 1979, Baile et al. 1981) due to its ability to produce acute inflammation and potently stimulate the release of numerous cytokines. One study of adjuvant-induced arthritis, a model for chronic inflammation in rats, demonstrated reduced plasma ghrelin levels and reduced weight gain in the first 7 days after arthritis induction, followed by a recovery of ghrelin levels to baseline and a partial recovery of weight gain during the second week of illness (Otero et al. 2004). Finally, Hanada et al. have demonstrated increasing plasma ghrelin levels as well as increasing ghrelin mRNA expression in the stomach in cachectic mice bearing human melanoma cells (Hanada et al. 2003), suggesting a compensatory increase in ghrelin levels with longstanding disease-associated weight loss. Together, these data suggest that enteric ghrelin cells are sensitive to inflammatory state and support a role for dysregulation of ghrelin secretion in inflammation-induced cachexia. The mechanisms of inflammation-induced ghrelin dysregulation and its potential role in inflammation-induced anorexia, however, remain unclear. In one recent study, it was found that peripheral injections of IL-1 $\beta$ could acutely suppress circulating ghrelin levels, and that the decrease in ghrelin brought about by LPS administration could be attenuated by blocking signaling either at the IL- $1 \beta$ receptor or by nonspecific inhibition of prostaglandin synthesis (Wang et al. 2006). However, another recent study demonstrated that acute anorexia brought about by peripheral IL- $1 \beta$ administration was completely independent of the synthesis of prostaglandin $E_{2}$ $\left(\mathrm{PGE}_{2}\right.$; Elander et al. 2007). To provide anatomical and pharmacological evidence for a model in which ghrelin is acutely regulated by IL- $1 \beta$ via a prostaglandin-dependent mechanism, we have investigated the cytokine receptor profile of enteric ghrelin-producing cells, as well as the chemical mediators of cell-cell communication likely to be involved in transmitting inflammatory signals to the ghrelin-producing cell. We hypothesize that the decrease in circulating levels of ghrelin in the setting of acute inflammation plays an important role in acute inflammation-associated anorexia, and that this decrease is mediated by local activation of IL- $1 \beta$ receptors with subsequent production of prostacyclin $\left(\mathrm{PGI}_{2}\right)$ that functions as a second messenger to enteric ghrelin cells.

\section{Materials and Methods}

\section{Animals}

Adult male Sprague-Dawley rats $(250-350 \mathrm{~g})$ were purchased from Charles River Laboratories (Wilmington, MA, USA). Type 1 IL-1 receptor knockout mice (IL-1RKO) and agematched wild-type (WT) controls were purchased from Jackson Laboratories (Bar Harbor, ME, USA). Rats or mice were housed two to three animals per cage, in a light-controlled $(12 \mathrm{~h}$ on/off; lights on at $0600 \mathrm{~h})$ and temperature-controlled $\left(22-23{ }^{\circ} \mathrm{C}\right)$ facilities and had access to standard speciesappropriate chow and water ad libitum except where otherwise noted. All studies were conducted in accordance with the NIH Guide for the Care and Use of Laboratory Animals and approved by the Animal Care and Use Committee of the Oregon Health \& Science University.

\section{LPS injection on plasma ghrelin and ghrelin $m R N A$ levels}

Three groups of rats were fasted overnight in clean cages, with food removed at the end of the light phase. The following morning, we injected one group with i.p. LPS (Sigma-Aldrich, $100 \mathrm{mcg} / \mathrm{kg}$ in $0.5 \%$ BSA (Sigma-Aldrich) in $0.9 \%$ saline; Basa et al. 2003) and a second group with i.p. vehicle only. Both groups remained fasting until the time of killing. A third group of rats received i.p. injection of vehicle and was allowed to refeed until the time of killing. All animals were killed $3 \mathrm{~h}$ later. Blood was collected into tubes containing K3 EDTA (BD Vacutainer) by cardiac puncture or trunk blood collection at the time of animal killing, and was processed as described below for ghrelin RIA. The stomachs were harvested and snap frozen on dry ice, then processed as described below for in situ hybridization. In a separate but otherwise identical study, the stomachs were removed and snap frozen for RNA extraction and real-time PCR analysis. Mice underwent an identical protocol with the additional step of harvesting hypothalamic blocks for ghrelin receptor (GHS-1R) analysis.

\section{Anti-inflammatory agent administration}

Five groups of rats were fasted overnight in clean cages, with food removed at the end of the light phase. The following morning, we injected one group with i.p. ketorolac (SigmaAldrich), an inhibitor of prostaglandin synthesis $(50 \mathrm{mg} / \mathrm{kg}$ in normal saline), and a second group with i.p. L-NAME (Sigma-Aldrich), a nitric oxide synthase inhibitor $(75 \mathrm{mg} / \mathrm{kg}$ in normal saline). One hour later, both of these pretreated groups, as well as a third group that had received no pretreatment, were injected with i.p. LPS $(100 \mu \mathrm{cg} / \mathrm{kg}$ in $0 \cdot 5 \%$ BSA saline). Also at this time, a fourth group received i.p. injections of vehicle. All groups remained fasting until 
the time of killing. A fifth group was injected with i.p. vehicle and allowed to refeed until the time of killing. All animals were killed $3 \mathrm{~h}$ after the LPS or saline injection. In a separate control study, three groups (ketorolac/saline, L-NAME/ saline, saline/saline) of fasting rats were used to test for independent effects of ketorolac or L-NAME on circulating ghrelin. These animals were treated exactly as above but saline was given instead of LPS at the $1-\mathrm{h}$ time point. Blood collection and processing for ghrelin RIA were performed as above.

\section{Prostaglandin injection}

In an initial series of experiments, rats were fasted overnight in clean cages for 15-18 h. In the morning, one group was injected with i.v. $\mathrm{PGE}_{2}$ (Sigma-Aldrich, $100 \mathrm{mcg} / \mathrm{kg}$ as $10 \mathrm{mcg} / \mathrm{mcl}$ EtOH diluted 1:10 in normal saline; Heylings \& Feldman 1988) via tail vein and the second group was injected with i.v. vehicle only (fasting $\mathrm{PGE}_{2}$ and fasting sham respectively). Both groups were killed 90 min later. Blood collection and processing for ghrelin RIA were performed as above. This protocol was repeated in fasting animals using a higher dose of $\mathrm{PGE}_{2}(300 \mathrm{mcg} / \mathrm{kg})$ with three experimental groups killed at 90,120, and $180 \mathrm{~min}$ postinjection as well as a control group treated with vehicle only.

The effects of carbocyclic thromboxane A2 (CTXA2, Cayman Chemical, Ann Arbor, MI, USA) and prostaglandin I2 (PGI2, Beraprost, Cayman Chemical) were investigated in four additional groups of animals using the same protocol described for $\mathrm{PGE}_{2}$. Two control groups were injected with i.p. vehicle only. One control group remained fasting (fasting sham) while the other was allowed to refeed until the time of killing (fed sham). One experimental group was injected with i.v. CTXA2 (500 $\mathrm{ng}$ as $1 \mathrm{mcg} / \mathrm{mcl} \mathrm{EtOH}$ diluted in $100 \mathrm{mcl}$ saline; Yanni et al. 1988, Omana-Zapata \& Bley 2001), and a second group was injected with i.p. PGI2 $(30 \mathrm{mcg} / \mathrm{kg}$ as $10 \mathrm{mcg} / \mathrm{mcl}$ EtOH diluted 1:250 in normal saline; Battal et al. 1996; fasting CTXA2 and fasting PGI2 respectively). All animals were killed $3 \mathrm{~h}$ after injection. Blood collection and processing for ghrelin RIA were performed as above.

\section{Plasma corticosterone levels}

Aliquots of plasma collected above at 90, 120, and $180 \mathrm{~min}$ post-PGE 2 injection and 90 min post-vehicle injection were assayed for corticosterone by a sensitive and specific RIA developed and performed using the Immunoassay Core Facility at Northwestern University (Evanston, IL, USA) according to their standard protocol. All samples were run in duplicate.

\section{Double-label immunohistochemistry}

Animals were deeply anesthetized with i.p. ketamine. Adequate anesthesia was judged by lack of response to tail or hind paw pinch. Animals were then perfused via the left cardiac ventricle with $250 \mathrm{ml}$ heparinized PBS, followed by $250 \mathrm{ml}$ of $4 \%$ paraformaldehyde in PBS. The stomachs were harvested and soaked in 20\% sucrose in PBS until they sank. Tissue was sliced in $30 \mu \mathrm{m}$ sections on a freezing sledge microtome and washed in $0.02 \mathrm{M}$ potassium PBS. Sections were incubated in $0 \cdot 25 \%$ BSA blocking buffer for $1 \mathrm{~h}$ at room temperature, and subsequently incubated in 1:800 rabbit antighrelin antibody (Phoenix Pharmaceuticals, Belmont, CA, USA) and 1:500 goat anti-IL-1 receptor (R\&D Systems, Minneapolis, MN, USA). We then utilized a commercial double-stain system to visualize ghrelin (with alkaline phosphatase) and the IL-1 receptor (with diaminobenzidine (DAB); Dako North America Inc., Carpinteria, CA, USA). Briefly, sections were immersed in dual endogenous enzyme block solution for $5 \mathrm{~min}$, washed, and then incubated in the first primary antibody. The sections were washed again, incubated in polymer/horseradish peroxidase (HRP) solution for $10 \mathrm{~min}$, washed again, and then incubated in DAB chromagen solution for $10 \mathrm{~min}$. This procedure was then repeated using an appropriate alkaline phosphatase secondary antibody and chromagen solution. The sections were then mounted on glass slides, dehydrated, and coverslipped.

\section{In situ hybridization}

Tissue preparation Snap frozen tissue harvested immediately after killing of experimental animals was stored at $-80{ }^{\circ} \mathrm{C}$ until use. The stomach was divided into four quadrants and representative sets of four slides each were taken from the center of these quadrants to control for potential regional differences in ghrelin expression throughout the stomach. The gastric tissue was cryostat sectioned in $20 \mu \mathrm{m}$ sections and thawmounted on SuperFrost Plus glass slides (VWR Scientific). Slides were also stored at $-80^{\circ} \mathrm{C}$.

Riboprobe preparation A ${ }^{33} \mathrm{P}$-labeled ghrelin cRNA riboprobe was produced using a partial ghrelin cDNA (322 bp) kindly provided by Dr Robert Steiner. The linearized plasmid was used to synthesize, by in vitro transcription, a radiolabeled, antisense cRNA riboprobe by inclusion of the following ingredients in a volume of $20 \mu \mathrm{l}: 250 \mu \mathrm{Ci}{ }^{33} \mathrm{P}-\mathrm{UTP}$ (NEN Life Science Products, Boston, MA, USA); $1 \mu \mathrm{g}$ linearized DNA; $0.5 \mathrm{mM}$ each ATP, CTP, GTP; and $20 \mathrm{U}$ SP6 RNA Polymerase-Plus (Ambion Inc., Austin, TX, USA). Residual DNA was digested with $10 \mathrm{U}$ DNase I (Roche Molecular Biochemicals) and the DNase reaction terminated by addition of $2 \mu \mathrm{l}$ of $0.5 \mathrm{M}$ EDTA. The yeast tRNA was added as a carrier $(10 \mu \mathrm{g})$ and the riboprobe was separated from unincorporated nucleotides with a NucAway Spin Column (Ambion) according to the manufacturer's protocol. A digoxigenin-labeled ghrelin cRNA riboprobe has also been produced from this clone and has demonstrated robust and specific labeling in the previous assays.

${ }^{33} \mathrm{P}$-labeled riboprobes for the $\mathrm{PGE}_{2}-\mathrm{EP} 1,3$, and 4 receptor subtypes, the thromboxane receptor and the PGI2 receptor were produced by the method described above. 
Partial cDNAs for the $\mathrm{PGE}_{2}-\mathrm{EP} 1,3$, and 4 receptors were generously provided by Dr Joel Elmquist. All cytokine receptor cDNAs were cloned from rat peripheral white blood cell mRNA and subcloned into pDP 18 (Ambion Inc.) for riboprobe transcription.

Single-label ISH Slides with mounted rat stomach sections were processed before hybridization as follows (all steps at room temperature): $5 \mathrm{~min}$ fix in $4 \%$ paraformaldehyde in $0.1 \mathrm{M}$ phosphate buffer, acetylated for $10 \mathrm{~min}$ in $0 \cdot 25 \%$ acetic anhydride in $0.1 \mathrm{M}$ triethanolamine, and delipidated for 5 min in chloroform. Radiolabeled, antisense ghrelin riboprobe was denatured, dissolved in hybridization solution, and applied with tRNA $(1.9 \mathrm{mg} / \mathrm{ml})$ to slides. Slides were covered with glass coverslips, placed in a humid chamber, and incubated overnight at $55^{\circ} \mathrm{C}$. The following day, slides were treated with RNase A $(29 \mu \mathrm{g} / \mathrm{ml}$; Sigma-Aldrich) and washed under conditions of increasing stringency, including two 30 -min washes in $0 \cdot 1 \times$ SSC $\left(15 \mathrm{mM} \mathrm{NaCl}, 1.5 \mathrm{mM}\right.$ sodium citrate) at $60^{\circ} \mathrm{C}$. Slides were subsequently dehydrated, air-dried, and dipped in NTB-2 liquid emulsion (Eastman Kodak Co.) diluted 1:1 with 600 mM ammonium acetate. Slides were developed and coverslipped when the optimal signal to background ratio of silver grains was achieved.

Double-label ISH Processing of slides with mounted rat stomach sections prior to probe hybridization proceeded as described above. For probe hybridization, radiolabeled antisense receptor riboprobes and digoxigenin-labeled ghrelin riboprobe were denatured, dissolved in hybridization solution containing tRNA and applied to slides. To demonstrate specificity of the receptor riboprobes, excess unlabeled antisense receptor riboprobe and radiolabeled sense receptor riboprobe were used as controls as described above for the ghrelin riboprobe. On day 2 , slides were treated with RNase $\mathrm{A}$ and washed twice in $0 \cdot 1 \times \mathrm{SSC}$ at $60{ }^{\circ} \mathrm{C}$. Slides were incubated in blocking buffer containing $2 \%$ normal sheep serum for $60 \mathrm{~min}$ then rinsed in buffer $1(100 \mathrm{mM}$ Tris, $150 \mathrm{mM} \mathrm{NaCl}, \mathrm{pH} \mathrm{7 \cdot 4)}$. Sections were then incubated in a humid chamber at $37^{\circ} \mathrm{C}$ for $3 \mathrm{~h}$ with a $1: 250$ dilution of antidigoxigenin antibody conjugated to alkaline phosphatase (Roche). Slides were subsequently rinsed in buffer 1 and buffer $2(150 \mathrm{mM}$ Tris, $\mathrm{pH} \mathrm{8 \cdot 3)}$ and then incubated for $45 \mathrm{~min}$ in Vector Red (Vector Laboratories, Burlingame, CA, USA) diluted in buffer 2 according to the manufacturer's protocol. Finally, the sections were rinsed in TE $(10 \mathrm{mM}$ Tris, $1 \mathrm{mM}$ EDTA, pH 8.0), dipped for $1 \mathrm{~min}$ in $100 \%$ ethanol, air-dried, and dipped in undiluted NTB-2 emulsion. Slides were developed and coverslipped when optimal signal to background ratio of silver grains was achieved.

\section{$R N A$ preparation and $R T-P C R$}

Total RNA was extracted using Qiagen RNeasy kits (Qiagen Inc.), DNA was removed from total RNA, using RNase-Free DNase (Qiagen Inc). RT reactions were prepared using a
TaqMan Reverse Transcription Kit (Applied Biosystems Inc., Foster City, CA, USA). For each reaction, cDNA synthesis was prepared using $500 \mathrm{ng}$ RNA in a reaction containing $4 \mu \mathrm{l}$ $10 \times$ RT buffer, $9 \mu \mathrm{l} 25 \mathrm{mM} \mathrm{MgCl} 2,8 \mu 10 \mathrm{mM}$ DNTPs, $1.5 \mu \mathrm{l} 50 \mu \mathrm{M}$ Random Hexamers, $1 \mu \mathrm{l}$ RNase Inhibitor, $1.5 \mu \mathrm{l}$ MulitScribe Reverse Transcriptase, and q.s. to $40 \mu \mathrm{l}$ with nuclease-free water. RT reactions were performed on an Eppendorf Mastercycler (Eppendorf AG, Hamburg, Germany) programed for $25^{\circ} \mathrm{C}$ for $10 \mathrm{~min}, 37^{\circ} \mathrm{C}$ for $1 \mathrm{~h}$, and $95^{\circ} \mathrm{C}$ for $5 \mathrm{~min}$. Samples were diluted with $40 \mu \mathrm{l}$ nuclease-free water stored at $4{ }^{\circ} \mathrm{C}$ until RT-PCR was performed.

RT-PCR was performed on an ABI 7300 real-time PCR System using rat-specific primer probe sets obtained from Applied Biosystems (Foster City, CA, USA). Each RT-PCR contained $10 \mu \mathrm{l}$ TaqMan Universal PCR Master Mix, $1 \mu \mathrm{l}$ Assays-on-demand Gene Expression Assay Mix, $4 \mu \mathrm{l}$ nuclease-free water, and $5 \mu \mathrm{l}$ cDNA. Samples and endogenous controls (Eukaryotic 18s rRNA) were run in duplicate to assure repeatability. Auto $C_{\mathrm{t}}$ values were calculated using 7300 RQ Study Software v.1.3 and verified.

\section{Ghrelin RIA}

Blood was collected from rats into collection tubes containing K3 EDTA (BD Vacutainer) and is stored on ice until processing. Plasma was separated by centrifugation at $2500 \mathrm{~g}$ at $4{ }^{\circ} \mathrm{C}$ for $10 \mathrm{~min}$, and stabilized with $50 \mathrm{mcl} 1 \mathrm{~N} \mathrm{HCl}$ and $10 \mathrm{mcl}$ phenylmethylsulfonyl fluoride per milliliter of plasma. Samples were stored at $-80^{\circ} \mathrm{C}$ until use. Ghrelin levels were determined in duplicate using the Linco Research Inc. (St. Charles, MO, USA) ghrelin (total) RIA kits according to the manufacturer's protocol. The manufacturer reports $100 \%$ specificity for this kit with a 3-10\% intra-assay coefficient of variation and a $10-16 \%$ inter-assay coefficient of variation.

\section{IL-1 $\beta$ ELISA}

Samples were harvested as described above and were analyzed with a commercial ELISA kit (R\&D Systems) according to the manufacturer's directions. Briefly, $50 \mu \mathrm{l}$ standards, controls, and samples were loaded into the ELISA plate and incubated for $2 \mathrm{~h}$ at room temperature, followed by five washes. The IL-1 conjugate was then added to each well and incubated for $2 \mathrm{~h}$ at room temperature, and then washed prior to incubating in substrate solution for $30 \mathrm{~min}$ in the dark. The reaction was stopped and the assay read on a microplate reader.

\section{Statistical analysis}

Statistical analysis of plasma ghrelin levels was performed using Microsoft Excel 2004 for Mac, version 11.0, and Prism 4 for Macintosh, version 4.0. Standard curves for each ghrelin assay were generated using the curve-fit function in Prism 4. Differences in plasma ghrelin levels between treatment groups were analyzed via one-way ANOVA, with post hoc Bonferroni calculations. For single-label in situ hybridization, clusters of 
silver grains corresponding to cells expressing ghrelin mRNA were counted and analyzed by silver grain counting software (Grains 1.0, a gift from Dr Donald Clifton, University of WA, Seattle, WA, USA). These data were then analyzed using a one-way ANOVA with post hoc Bonferroni analysis to investigate differences between groups. All data are reported as mean \pm s.E.M. and all graphs depict data as mean \pm s.E.M. $P$ values $<0 \cdot 05$ are considered statistically significant.

\section{Results}

\section{LPS suppresses plasma ghrelin levels}

Fed rats $(n=14)$ had significantly lower ghrelin levels than fasted rats $(n=17$; fasted $3765 \pm 164 \mathrm{pg} / \mathrm{ml}$ versus fed $1843 \pm$ $154 \mathrm{pg} / \mathrm{ml}, P<0 \cdot 001)$ and LPS treatment $(n=17)$ reduced fasting ghrelin levels to levels seen in fed controls (fed 1843 $154 \mathrm{pg} / \mathrm{ml}$ versus fasted + LPS $2372 \pm 150 \mathrm{pg} / \mathrm{ml}, P>0 \cdot 05)$ confirming earlier studies from other investigators. Data are shown in Fig. 1.

\section{LPS does not alter ghrelin $m R N A$ levels}

To investigate the possibility that acute inflammation inhibits the transcription of the ghrelin gene, we performed singlelabel in situ hybridization analysis as described above. We found that ghrelin mRNA was robustly expressed in cells near the base of the muscularis mucosa (MM), with cells scattered toward the luminal surface generally having a relatively weaker hybridization signal (Fig. 2A-C). We found no difference between groups in overall gastric ghrelin mRNA levels between groups (expressed as a percentage of the fasted average grain counts: fasted $100 \pm 3 \%$, fed $101 \pm 6 \%$, LPS $107 \pm 5 \%$, ANOVA $P=0 \cdot 6, n=11$ per group; Fig. $2 \mathrm{D})$, and no difference was observed when the data were divided by region of the stomach (not shown). These data were confirmed with RT-PCR analysis from a second group of animals (expressed as a percentage of the fasted average: fasted

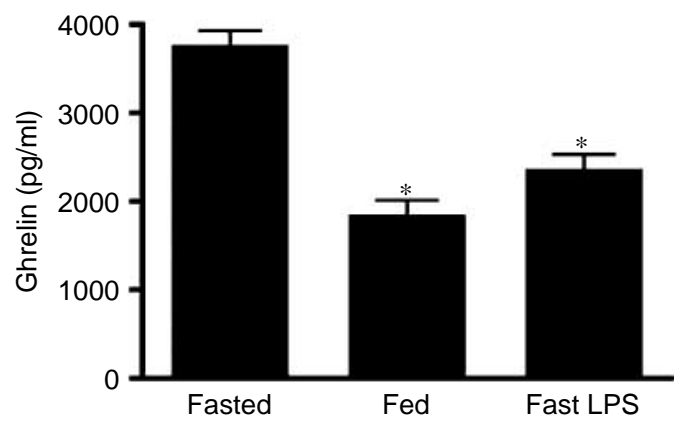

Figure 1 Effect of acute inflammation on plasma ghrelin levels. Treatment of fasted rats with LPS $100 \mathrm{mcg} / \mathrm{kg}(n=17)$ resulted in a $37 \%$ decrease in the plasma ghrelin level at $3 \mathrm{~h}$ when compared with fasted rats injected with vehicle only $(n=17 ; * P<0 \cdot 001$ versus fasted control). I.P. injection of LPS reduced plasma ghrelin to a level similar to that seen in rats injected with vehicle only and allowed to refeed for $3 \mathrm{~h}$ prior to killing $(n=14 ; P>0 \cdot 05)$.
$100 \pm 19 \%$, fed $98 \pm 29 \%$, LPS $101 \pm 6 \%$, ANOVA $P=0.99$, $n=4$ per group; Fig. 2E).

Enteric ghrelin-producing cells express the type $1 \mathrm{IL}-1 \beta$ receptor

Double-label in situ hybridization was employed to identify the distribution of ghrelin mRNA and type 1 IL-1 $\beta$ receptor (IL-1R1) mRNA in sections of the stomach. Intense ghrelin mRNA staining is seen in cells at the base of the mucosal layer near blood vessels, and to a lesser extent, throughout the mucosal villi (MV), but not in the MM (Fig. 3A). Although no ghrelin cells appear to co-localize the IL-1R1 mRNA, intense IL-1R1 mRNA expression is seen in cells at the base of the gastric mucosa in close approximation to cells expressing ghrelin. Double-label immunohistochemistry (Fig. 3B) confirms that the ghrelin and IL-1R1 protein distributions match the mRNA expression patterns seen in Fig. 2A.

COX blockade reverses the effect of LPS on plasma ghrelin levels

Fasted animals treated with LPS $(n=13)$ showed suppression of total ghrelin to levels seen in fed controls $(n=10$; LPStreated: $2454 \pm 180 \mathrm{pg} / \mathrm{ml}$ versus fed controls: $2010 \pm$ $191 \mathrm{pg} / \mathrm{ml}, P>0 \cdot 05)$. Pretreatment with ketorolac $(n=10)$ reversed this effect (ketorolac+LPS-treated: $3261 \pm$ $191 \mathrm{pg} / \mathrm{ml}$ versus LPS-treated: $2454 \pm 180 \mathrm{pg} / \mathrm{ml}, P<0 \cdot 05)$. Pretreatment with L-NAME $(n=4)$ did not reverse the effect of LPS-induced inflammation on ghrelin levels. Data are shown in Fig. 4A. Fed and fasted control animals not treated with drug or LPS were given saline injections at the appropriate experimental time points. To rule out nonspecific anti-inflammatory effects of our drug treatments, we determined the circulating levels of IL-1 $\beta$ in these same animals. At baseline, the circulating IL-1 levels were at or below the lower limits of detection in all groups. After LPS and drug treatment, all LPS-treated groups showed elevated IL-1 levels that were not different between groups (LPStreated: $325 \pm 172 \mathrm{pg} / \mathrm{ml}$ versus ketorolac + LPS-treated: $297 \pm 110 \mathrm{pg} / \mathrm{ml}$ versus $\mathrm{LL}+\mathrm{LPS}-$ treated: $356 \pm 165 \mathrm{pg} / \mathrm{ml}$, $P=0.9)$. In a separate control study, ketorolac $(n=5)$ and L-NAME $(n=5)$ did not have an independent effect on fasting ghrelin levels relative to saline control $(n=5$; fasted saline $3570 \pm 264$, fasted ketorolac $3389 \pm 306$, fasted L-NAME $3463 \pm 497, P=0 \cdot 94)$.

\section{Prostacyclin injection decreases plasma ghrelin levels}

Fasted animals treated with i.v. $\mathrm{PGE}_{2}$ showed no difference in plasma ghrelin levels at $90 \mathrm{~min}(n=6 ; 5416 \pm 205 \mathrm{pg} / \mathrm{ml})$, $120 \mathrm{~min}(n=6 ; 5046 \pm 164 \mathrm{pg} / \mathrm{ml})$, or $180 \mathrm{~min} \quad(n=4$; $5543 \pm 178 \mathrm{pg} / \mathrm{ml})$ when compared with fasted controls injected with vehicle only $(n=6 ; 5369 \pm 93 \mathrm{pg} / \mathrm{ml}, P>0 \cdot 05$ for all comparisons). Data are shown in Fig. 4B.

Fasted animals treated with CTXA2 $(n=6)$ demonstrated ghrelin levels similar to fasted controls treated with vehicle only ( $n=4$; CTXA2-treated: $2861 \pm 194 \mathrm{pg} / \mathrm{ml}$ versus fasted 

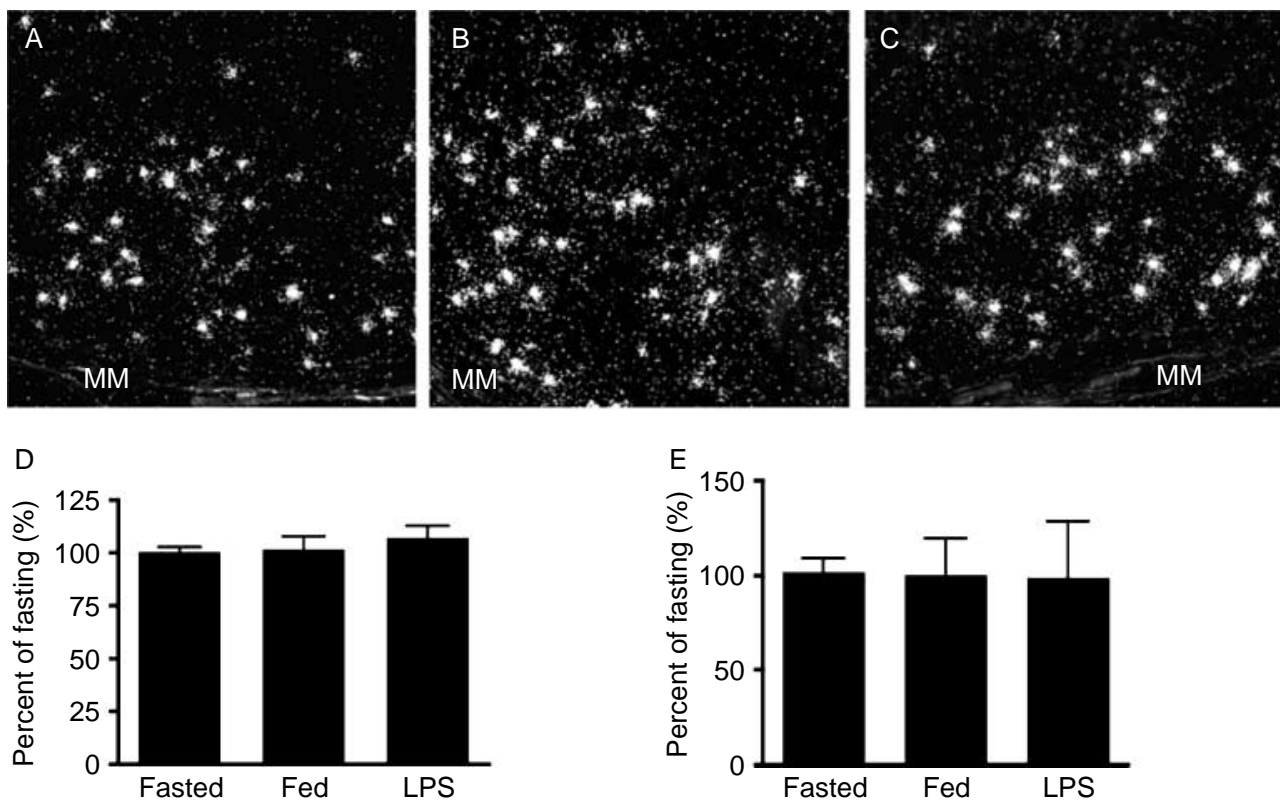

Figure 2 (A-C) Representative images of single-label in situ hybridization for ghrelin mRNA in gastric mucosa from fasted (A), fed (B), and fasted, LPS-treated animals $(C)$. The border of the muscularis mucosa $(M M)$ is indicated. (D) Semi-quantitative analysis of relative ghrelin mRNA expression as measured by in situ hybridization and computerized grain counting analysis. All data are normalized to the average grain count value for the fasted group. (E) Real-time PCR analysis of ghrelin mRNA expression. All data are normalized to the average value for the fasted group.

controls: $3515 \pm 262 \mathrm{pg} / \mathrm{ml}, P>0 \cdot 05)$. Fasted animals treated with PGI2 $(n=6)$ showed a significant decrease in plasma ghrelin compared with fasted controls (PGI2-treated: $2023 \pm$ $90 \mathrm{pg} / \mathrm{ml}$ versus fasted controls: $3515 \pm 262 \mathrm{pg} / \mathrm{ml}$, $P<0 \cdot 001)$ and compared with CTXA2-treated animals $(P<0 \cdot 01)$. Treatment with PGI2 did not fully suppress ghrelin to levels seen in fed controls (PGI2-treated: 2023 \pm $90 \mathrm{pg} / \mathrm{ml}$ versus fed controls: $958 \pm 5 \mathrm{pg} / \mathrm{ml}, P>0 \cdot 05)$. Data are shown in Fig. 4C.

Plasma corticosterone levels are elevated by prostaglandin injections

As a positive physiological control for the $\mathrm{PGE}_{2}$ injections, we measured plasma corticosterone levels after injection. Corticosterone levels differed significantly in fasted rats treated with $\mathrm{PGE}_{2}(n=6)$ when compared with fasted rats treated with vehicle only $(n=6)$ with levels measured at a single 90 -min time point $\left(\mathrm{PGE}_{2}\right.$-treated: $788 \pm 85 \mathrm{ng} / \mathrm{ml}$ versus fasted controls: $446 \pm 17 \mathrm{ng} / \mathrm{ml}, P=0 \cdot 0016)$.

Enteric ghrelin-producing cells express prostacyclin receptor $m R N A$

Double-label in situ hybridization assays did not demonstrate co-localization of ghrelin mRNA with receptor mRNA for the $\mathrm{PGE}_{2}$ receptor subtypes (EP1, 2, 3, or 4), nor was there evidence for co-localization of the ghrelin mRNA and the thromboxane A2 receptor (data not shown). In each case, expression of these receptors was observed in positive control tissues (rat brain sections, not shown). In contrast, mRNA for the prostacyclin PGI2 receptor was diffusely expressed in the rat stomach, including wide expression along the base of the MV where the majority of enteric ghrelin-producing cells reside and a majority of ghrelin-producing cells expressed this mRNA (Fig. 5).

\section{LPS does not suppress circulating ghrelin in the IL-1 receptor knockout mouse}

To confirm the role of IL-1 in the regulation of ghrelin secretion, we undertook a separate series of experiments in the IL-1 RKO mouse. In the first study, we demonstrated that LPS did not have an effect on enteric ghrelin mRNA (Fig. 6a) or on the hypothalamic expression of the GHS-1R (Fig. 6b). As shown in Fig. 6c, LPS administration decreased circulating ghrelin in WT, but failed to decrease circulating ghrelin in IL-1 RKO mice (fed 2294 $\pm 181, n=4$; fasted saline WT $5367 \pm 551, n=8$; WT fasted LPS $3145 \pm 206$, $n=8$; IL-1RKO fasted saline $3360 \pm 192, n=8$; IL-1RKO fasted LPS $4214 \pm 257, n=8$; ANOVA $P<0 \cdot 001$, Fig. 6). Interestingly, fasted, saline-injected WT, and IL-1RKO mice had different ghrelin levels at baseline $(P<0 \cdot 001$ by post hoc Bonferroni), indicating that there may be an effect of IL-1 on the baseline physiology or development of the ghrelin cells. 


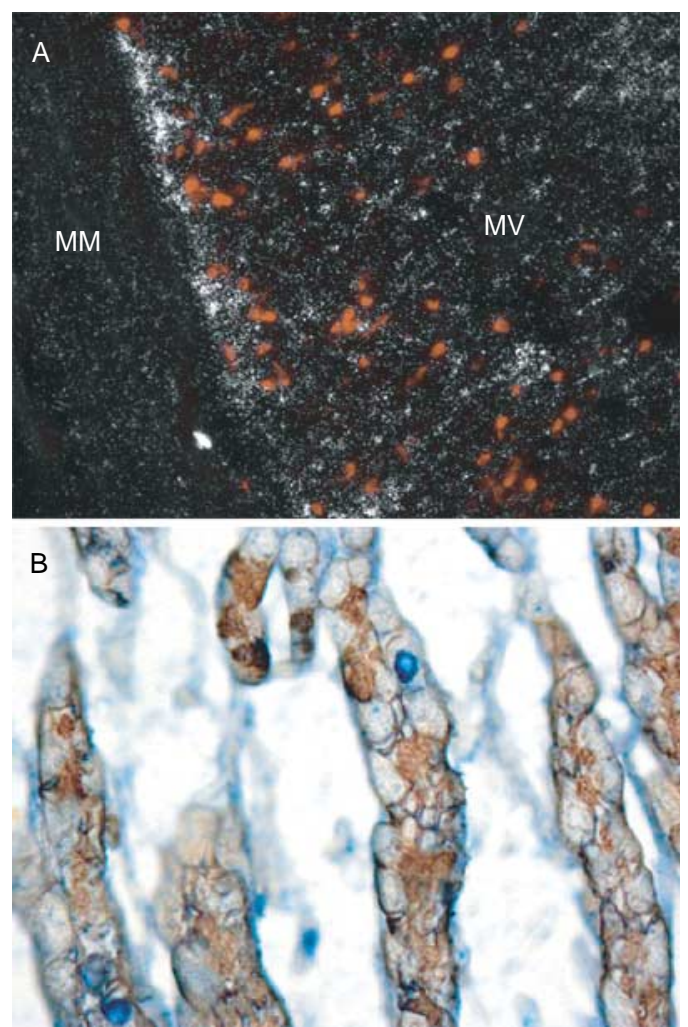

Figure 3 (A) Double-label in situ hybridization for ghrelin mRNA and type 1 IL- $1 \beta$ receptor mRNA in the rat stomach. Ghrelinexpressing cells are labeled with a digoxigenin cRNA probe (red label); IL-1R1 cells are labeled with a ${ }^{33}$ P-labeled cRNA probe and radiographic emulsion (white silver grain clusters). $\mathrm{MM}$, muscularis mucosa; MV, mucosal villi. (B) High power $(400 \times)$ view of doublelabel immunohistochemistry for ghrelin and type 1 IL-1R1 protein in the rat stomach. Section stained for ghrelin using alkaline phosphatase (blue chromagen) and IL-1 $\beta-\mathrm{R}$ using horseradish peroxidase (brown chromagen).

\section{Discussion}

Animals have evolved numerous advantageous behavioral and metabolic adaptations designed to maximize survival from an acute infection. Although largely speculative, many authors have pointed out that acute anorexia in the setting of an infection may provide benefit to the animal for a variety of reasons. First, the decrease in food intake would tend to diminish the ingestion of micronutrients such as iron that are essential for pathogen survival, and thereby provide an acute survival advantage (Kluger \& Rothenburg 1979, Weinberg 1984). Second, foraging behavior is metabolically expensive, and potentially exposes the animal to increased evaporative heat loss and predation with the net effect of decreased survival (Hart 1985, 1988). Thus, while anorexia and a net catabolic state are obviously deleterious in the setting of chronic disease (where it manifests as cachexia), during acute inflammation it may provide a net survival benefit. In spite of the remarkable conservation of the acute illness response throughout the animal kingdom, until recently relatively little was known about its pathophysiology. Data derived from numerous sources now points to a model wherein proinflammatory cytokines (including IL-1 $\beta$, IL-6, and tumor necrosis factor- $\alpha$ (TNF- $\alpha$ ), among others) are produced by the immune system in response to pathogens, and these cytokines then signal both directly and indirectly to feeding centers in the CNS to produce the stereotypical sickness behavior response (Inui 1999a, Ramos et al. 2004, Deboer \& Marks 2006). However, several lines of evidence suggest that the mechanisms of acute inflammation-induced anorexia may be distinct (at least in part) from those present in a chronic inflammatory state. For example, the acute anorexic effects of peripheral administration of IL-1 $\beta$ appear to be dependent on prostaglandin synthesis (Hellerstein et al. 1989, Elander et al. 2007) whereas inhibiting prostaglandin synthesis in chronic disease states has proven to have relatively little effect on food intake (McCarthy 1999, Lundholm et al. 2004).

Many lines of evidence indicate that the central melanocortin system plays a key role in the tonic regulation of body weight in healthy individuals and that excessive activation of this system is one important mechanism in the production of cachexia in chronic disease states (Marks et al. 2001, Cheung et al. 2005, Markison et al. 2005). Other evidence suggests that this system may play a role in the acute regulation of appetite by ghrelin on a meal-to-meal basis as well. Recent studies have demonstrated that ghrelin stimulates the activity of orexigenic neuropeptide Y (NPY) neurons in the hypothalamus and that the acute orexigenic effect of peripheral ghrelin is abolished in the absence of NPY and the endogenous melanocortin antagonist, agouti-related peptide (AgRP; Cowley et al. 2003, Chen et al. 2004). Thus, an acute decrease in circulating ghrelin would be expected to produce hypophagia by increasing the net melanocortinergic tone in the hypothalamus. Our data, as well as that of others, indicate that circulating ghrelin levels are acutely decreased in the setting of LPS- or cytokine-induced inflammation (Basa et al. 2003, Hataya et al. 2003, Wang et al. 2006). Thus, previous observations that acute anorexia brought about by the administration of LPS or IL-1 $\beta$ is attenuated in models of impaired melanocortin signaling may provide further evidence that the melanocortin system lies downstream of the ghrelin signal to feeding centers in the brain (Lawrence \& Rothwell 2001, Marks et al. 2001, Joppa et al. 2005).

Our data have confirmed the observation of others that circulating ghrelin levels in fasted animals are acutely decreased by LPS administration to levels found in fed animals. Furthermore, we have used in situ hybridization and RT-PCR to demonstrate that this does not appear to be due to a change in ghrelin gene expression in the gut, either globally, or in a region-specific fashion. Thus, the acute alteration in circulating ghrelin is likely to be due to some combination of a decrease in secretion and an increase in breakdown and clearance from the circulation. Because LPS is known to acutely decrease renal function and ghrelin appears to be primarily cleared from the circulation by the kidney, it is 

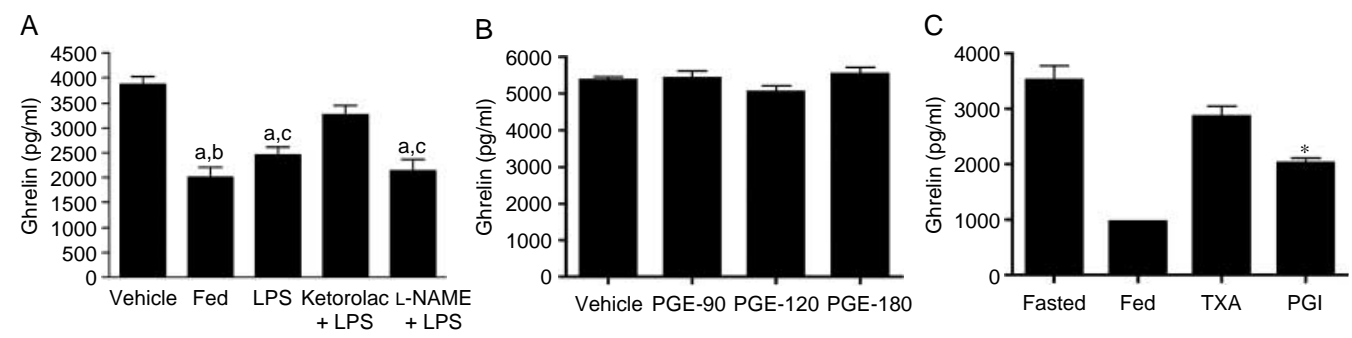

Figure 4 Effect of prostaglandins on plasma ghrelin levels. (A) Fasted rats treated with LPS (100 mcg/kg; $n=13)$ showed suppression of total ghrelin to levels seen in fed controls $(n=10$; LPS-treated: $2454 \pm 180 \mathrm{pg} / \mathrm{ml}$ versus fed controls: $2010 \pm$ $191 \mathrm{pg} / \mathrm{ml}, P>0 \cdot 05)$. Pretreatment with i.p. ketorolac $(50 \mathrm{mg} / \mathrm{kg} ; n=10)$ attenuated this effect (ketorolac + LPS-treated: $3261 \pm 191 \mathrm{pg} / \mathrm{ml}$ versus LPS-treated: $2454 \pm 180 \mathrm{pg} / \mathrm{ml}, P<0 \cdot 05)$. Pretreatment with i.p. L-NAME (75 mg/kg; $n=4) \mathrm{did}$ not reverse the effect of LPS-induced inflammation on ghrelin levels. (B) Treatment of fasted rats with i.v. prostaglandin $E_{2}$ $(300 \mathrm{mcg} / \mathrm{kg})$ had no effect on plasma ghrelin levels at $90(n=6), 120(n=6)$ or $180(n=4)$ min when compared with rats treated with i.v. vehicle only $(n=6)$. (C) Treatment of fasted rats with i.p. prostaglandin I2 analog $(30 \mathrm{mcg} / \mathrm{kg} ; n=6)$ resulted in a $42 \%$ decrease in plasma ghrelin levels when compared with fasted rats treated with vehicle only $(n=4 ; P<0 \cdot 001)$. Treatment of fasted rats with i.v carbocyclic thromboxane A2 (500 ng; $n=6$ ) did not significantly decrease plasma ghrelin levels when compared with fasted controls $(P>0 \cdot 05)$.

likely that the acute decrease in circulating ghrelin in this study was due to a rapid decrease in its secretion from the stomach rather than an increase in renal clearance (GuebreEgziabher et al. 2005, Jarkovska et al. 2005). Indeed, direct measurements of the half-life of radiolabeled ghrelin indicate that its circulating half-life is unchanged early in inflammation, and actually increases as the duration of the inflammatory stimulus increases (Wu et al. 2003). Obviously, changes in the rate of translation of the mRNA and changes in posttranslational processing of the peptide may also occur but were not measured here. We also found no evidence that

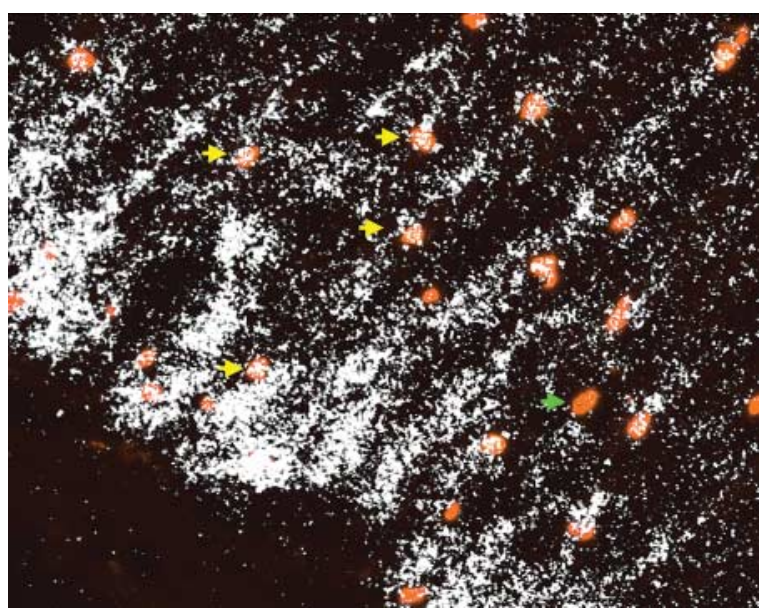

Figure 5 Double-label in situ hybridization for ghrelin mRNA and the prostacyclin I2 (PGI2-R) receptor mRNA in the rat stomach. Ghrelin-expressing cells are labeled with a digoxigenin cRNA probe (red label); PGI2-R cells are labeled with a ${ }^{33}$ P-labeled cRNA probe and radiographic emulsion (white silver grain clusters). The majority of ghrelin mRNA-expressing cells also express PGI2-R (yellow arrows) although occasional cells do not appear to express PGI2-R message (green arrow). the expression of the ghrelin receptor in the hypothalamus is altered either by feeding status or by inflammation.

LPS exerts the majority of its acute effects by increasing the production of proinflammatory cytokines. We therefore sought to provide anatomical evidence that cells within the gastric mucosa (potentially including ghrelin-expressing cells) express receptors for these cytokines. Both TNF- $\alpha$ and IL-6 have been shown to stimulate proliferation of cultured gastric epithelial cells, and they are thought to play a role in normal gastric repair as well as in tumorigenesis (Shirota et al. 1990, Howlett et al. 2005, Luo et al. 2005, Giraud et al. 2007). However, we were unable to detect a significant level of expression of the TNF- $\alpha$ receptor, leukemia inhibitory factor receptor (LIF-R), or the gp130 subunit common to the entire IL-6 class of cytokines in our in situ hybridization assays (data not shown). Obviously, our assay may simply not be sensitive enough to detect a relatively low level of expression of these genes. Alternatively, it is possible that these receptors are primarily expressed on gastric tumors or inflamed gastric mucosa in a manner analogous to the expression of the IL-6 receptor in colonic carcinomas (Shirota et al. 1990). In contrast, we demonstrated robust expression of IL-1R1 mRNA and protein in the gastric mucosa, primarily distributed at the base of the gastric mucosa, and extending to a limited extent toward the luminal surface. These data are consistent with previously published reports of IL-1R1 expression in freshly isolated rat parietal cells as well as in gastric carcinoma cell lines (Beales \& Calam 1998, Schepp et al. 1998, Beales 2002). Although the tissue distribution of IL-1R 1 matches the distribution of ghrelin-producing cells, we found no evidence of colocalization of ghrelin with the IL-1R1, indicating that the effect of IL-1 $\beta$ on ghrelin secretion is due to the paracrine action of a second messenger.

Previous investigators demonstrated that peripheral administration of IL- $1 \beta$ acutely decreased circulating ghrelin, and that this effect was blocked by globally inhibiting 
A Stomach ghrelin gene expression

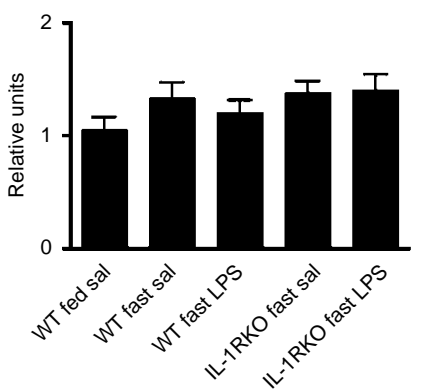

B

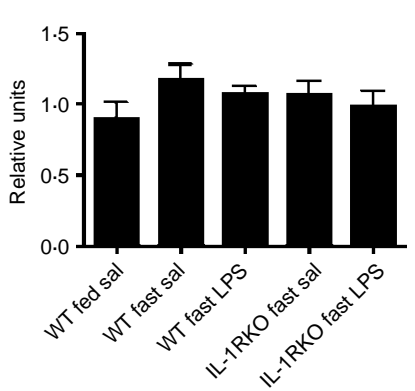

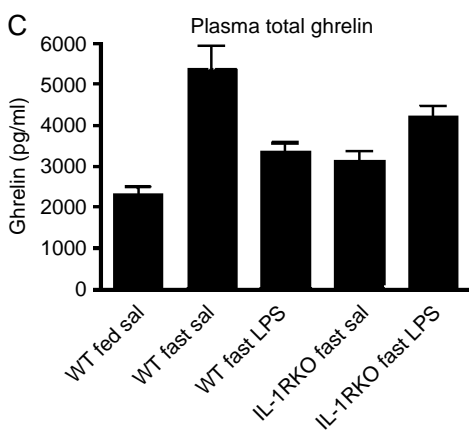

Figure 6 Effect of acute inflammation on gastric ghrelin gene expression, hypothalamic GHS-1R expression, and plasma ghrelin levels in IL-1R KO mice. (A and B) Treatment of fasted mice with LPS $100 \mathrm{mcg} / \mathrm{kg}$ ( $n=4$ (fed), $n=8$ (all other groups) did not change enteric ghrelin gene expression, or expression of the GHS-1R in the hypothalamus. (C) This same treatment resulted in a 59\% decrease in the plasma ghrelin level in WT mice at $3 \mathrm{~h}$ when compared with fasted mice injected with vehicle only $(a=P<0.01$ versus fasted saline control, $b=P<0.05$ versus IL-1RKO LPS). I.P. injection of LPS in WT mice reduced plasma ghrelin to a level similar to that seen in mice injected with vehicle only and allowed to refeed for $3 \mathrm{~h}$ prior to killing. In contrast, LPS injection did not result in a decrease in circulating ghrelin in IL-1R KO mice $(P>0 \cdot 05)$.

prostaglandin synthesis with indomethacin (Wang et al. 2006). However, other investigators demonstrated that the anorexia brought about by peripheral IL- $1 \beta$ injection was not dependent on the synthesis of $\mathrm{PGE}_{2}$ (Elander et al. 2007). Thus, we sought to resolve these conflicting data by exploring the effect of various second messenger systems in the acute ghrelin response to LPS. Nitric oxide is produced as a second messenger in the gut where it plays a critical role in numerous processes that maintain gastric mucosal integrity including mucus secretion, gastric blood flow, and modulation of regional immune function (Calatayud et al. 2001, Martin et al. 2001). However, our data suggest that the production of nitric oxide is not necessary for the acute decrease in ghrelin by LPS administration. In contrast, our data are in agreement with those of Wang et al. and demonstrate that nonspecific inhibition of prostaglandin synthesis with keterolac reverses the effects of LPS on circulating ghrelin. We therefore sought to provide pharmacological and histological evidence that ghrelin-expressing cells are responsive to prostaglandins. In an initial series of experiments, we found that i.v. injection of $\mathrm{PGE}_{2}$ had no effect on circulating ghrelin levels, at least at the time points studied. This same injection nearly doubled plasma corticosterone levels, confirming that this injection provided a significant physiological stimulus to the animals. Similarly, we found that thromboxane $\mathrm{A}_{2}$ caused only a small trend toward decreasing circulating ghrelin. In contrast, prostacyclin $\left(\mathrm{PGI}_{2}\right)$ decreased circulating ghrelin levels to a similar degree as was found with injection of LPS. We then used double-label in situ hybridization analysis to demonstrate that ghrelin-producing cells also express receptors for various end products of the cyclooxygenase (COX) pathway. We found only relatively weak and variable mucosal labeling for the $\mathrm{PGE}_{2}-\mathrm{EP} 1,3$, and 4 receptor subtypes as well as the thromboxane receptor, and could find no evidence of colocalization with ghrelin-positive cells. In contrast, we found robust expression of $\mathrm{PGI}_{2}$ receptor mRNA in the majority of ghrelin-positive cells, as well as in cells in close proximity to ghrelin cells.

From these data as well as those of other groups, we conclude that the decrease in circulating ghrelin induced by acute inflammation is brought about by activation of the IL-1R1, and hypothesize that the primary site of action in this case is in the gastric mucosa, with subsequent elaboration and binding of the second messenger $\mathrm{PGI}_{2}$ on gastric ghrelin cells. It remains possible that ghrelin is altered by a feedback loop that involves processing of the inflammatory signal at the level of the CNS, and this possibility will need to be addressed in future studies. Although not specifically tested in these studies, it is likely that $\mathrm{PGI}_{2}$ exerts its effects primarily by acutely decreasing the secretion of ghrelin from these enteric cells. IL-1 $\beta$ has been previously shown to increase the production of $\mathrm{PGI}_{2}$ in numerous other tissues, primarily by upregulating the expression and action of COX-2 (Belt et al. 1999, Caughey et al. 2001, Walch and Morris 2002, Itoh et al. 2003). Obviously, one of the outcomes of this acute decrease in circulating ghrelin would be the development of anorexia as is typical of the acute illness response. However, because ghrelin has important anti-inflammatory properties, it is possible that decreasing ghrelin may enhance the overall inflammatory response to an acute immune challenge (Dixit et al. 2004, Granado et al. 2005, Gonzalez-Rey et al. 2006). Indeed, several recent studies suggest that ghrelin may be effective in decreasing the severity of septic shock and this is likely to be due, in part, to its efficacy in acutely decreasing inflammation (Chang et al. 2003a,b, Wu et al. 2005). This emphasizes the potential therapeutic benefit of ghrelin and ghrelin analogs in acute inflammation, and supports the idea that these compounds may be beneficial in chronic illnesses as well. 


\section{Acknowledgements}

We thank Dr Christopher Coreless for his assistance with the dual-label immunohistochemistry. This work is supported by NIH NIDDK 70333 and 062207. The authors declare that there is no conflict of interest that would prejudice the impartiality of this scientific work.

\section{References}

Ariyasu H, Takaya K, Tagami T, Ogawa Y, Hosoda K, Akamizu T, Suda M, Koh T, Natsui K, Toyooka S et al. 2001 Stomach is a major source of circulating ghrelin, and feeding state determines plasma ghrelin-like immunoreactivity levels in humans. Journal of Clinical Endocrinology and Metabolism 86 4753-4758.

Baile CA, Naylor J, McLaughlin CL \& Catanzaro CA 1981 Endotoxinelicited fever and anorexia and elfazepam-stimulated feeding in sheep. Physiology and Behavior 27 271-277.

Basa NR, Wang L, Arteaga JR, Heber D, Livingston EH \& Tache Y 2003 Bacterial lipopolysaccharide shifts fasted plasma ghrelin to postprandial levels in rats. Neuroscience Letters 343 25-28.

Battal MN, Hata Y, Matsuka K, Ito O, Matsuda H, Yoshida Y \& Kawazoe T 1996 Reduction of progressive burn injury by a stable prostaglandin I2 analogue, beraprost sodium (procylin): an experimental study in rats. Burns 22 531-538.

Beales IL 2002 Effect of interlukin-1beta on proliferation of gastric epithelial cells in culture. BMC Gastroenterology 27.

Beales IL \& Calam J 1998 Interleukin 1 beta and tumour necrosis factor alpha inhibit acid secretion in cultured rabbit parietal cells by multiple pathways. Gut 42 227-234.

Belt AR, Baldassare JJ, Molnar M, Romero R \& Hertelendy F 1999 The nuclear transcription factor NF- $\kappa \mathrm{B}$ mediates interleukin- $1 \beta$-induced expression of cyclooxygenase-2 in human myometrial cells. American Journal of Obstetrics and Gynecology 181 359-366.

Calatayud S, Barrachina D \& Esplugues JV 2001 Nitric oxide: relation to integrity, injury, and healing of the gastric mucosa. Microscopy Research and Technique 53 325-335.

Caughey GE, Cleland LG, Penglis PS, Gamble JR \& James MJ 2001 Roles of cyclooxygenase (COX)-1 and COX-2 in prostanoid production by human endothelial cells: selective up-regulation of prostacyclin synthesis by COX2. Journal of Immunology 167 2831-2838.

Chang L, Du JB, Gao LR, Pang YZ \& Tang CS 2003a Effect of ghrelin on septic shock in rats. Acta Pharmacologica Sinica 24 45-49.

Chang L, Zhao J, Yang J, Zhang Z, Du J \& Tang C 2003b Therapeutic effects of ghrelin on endotoxic shock in rats. European Journal of Pharmacology 473 171-176.

Chen HY, Trumbauer ME, Chen AS, Weingarth DT, Adams JR, Frazier EG, Shen Z, Marsh DJ, Feighner SD, Guan XM et al. 2004 Orexigenic action of peripheral ghrelin is mediated by neuropeptide $\mathrm{Y}$ and agouti-related protein. Endocrinology 145 2607-2612.

Cheung W, Yu PX, Little BM, Cone RD, Marks DL \& Mak RH 2005 Role of leptin and melanocortin signaling in uremia-associated cachexia.

Journal of Clinical Investigation 115 1659-1665.

Cowley MA, Smith RG, Diano S, Tschop M, Pronchuk N, Grove KL, Strasburger CJ, Bidlingmaier M, Esterman M, Heiman ML et al. 2003 The distribution and mechanism of action of ghrelin in the CNS demonstrates a novel hypothalamic circuit regulating energy homeostasis. Neuron 37 649-661.

Cummings DE, Purnell JQ, Frayo RS, Schmidova K, Wisse BE \& Weigle DS 2001 A preprandial rise in plasma ghrelin levels suggests a role in meal initiation in humans. Diabetes 50 1714-1719.

Deboer MD \& Marks DL 2006 Cachexia: lessons from melanocortin antagonism. Trends in Endocrinology and Metabolism 17 199-204.
Dixit VD, Schaffer EM, Pyle RS, Collins GD, Sakthivel SK, Palaniappan R, Lillard JW Jr \& Taub DD 2004 Ghrelin inhibits leptin- and activationinduced proinflammatory cytokine expression by human monocytes and $\mathrm{T}$ cells. Journal of Clinical Investigation 114 57-66.

Elander L, Engstrom L, Hallbeck M \& Blomqvist A 2007 IL-1 $\beta$ and LPS induce anorexia by distinct mechanisms differentially dependent on microsomal prostaglandin E synthase-1. American Journal of Physiology. Regulatory, Integrative and Comparative Physiology 292 R258-R267.

Giraud AS, Jackson C, Menheniott TR \& Judd LM 2007 Differentiation of the Gastric Mucosa IV. Role of trefoil peptides and IL-6 cytokine family signaling in gastric homeostasis. American Journal of Physiology. Gastrointestinal and Liver Physiology 292 G1-G5.

Gonzalez-Rey E, Chorny A \& Delgado M 2006 Therapeutic action of ghrelin in a mouse model of colitis. Gastroenterology 130 1707-1720.

Granado M, Priego T, Martin AI, Villanua MA \& Lopez-Calderon A 2005 Anti-inflammatory effect of the ghrelin agonist growth hormone-releasing peptide-2 (GHRP-2) in arthritic rats. American Journal of Physiology. Endocrinology and Metabolism 288 E486-E492.

Guebre-Egziabher F, Bernhard J, Geelen G, Malvoisin E, Hadj-Aissa A \& Fouque D 2005 Leptin, adiponectin, and ghrelin dysregulation in chronic kidney disease. Journal of Renal Nutrition 15 116-120.

Hanada T, Toshinai K, Kajimura N, Nara-Ashizawa N, Tsukada T, Hayashi Y, Osuye K, Kangawa K, Matsukura S \& Nakazato M 2003 Anti-cachectic effect of ghrelin in nude mice bearing human melanoma cells. Biochemical and Biophysical Research Communications 301 275-279.

Hart BL 1985 Animal behavior and the fever response: theoretical considerations. Journal of American Veterinary Medical Association 187 998-1001.

Hart BL 1988 Biological basis of the behavior of sick animals. Neuroscience and Biobehavioral Reviews 12 123-137.

Hataya Y, Akamizu T, Hosoda H, Kanamoto N, Moriyama K, Kangawa K, Takaya K \& Nakao K 2003 Alterations of plasma ghrelin levels in rats with lipopolysaccharide-induced wasting syndrome and effects of ghrelin treatment on the syndrome. Endocrinology 144 5365-5371.

Hellerstein MK, Meydani SN, Meydani M, Wu K \& Dinarello CA 1989 Interleukin-1-induced anorexia in the rat. Influence of prostaglandins. Journal of Clinical Investigation 84 228-235.

Heylings JR \& Feldman M 1988 Basal and $\mathrm{PGE}_{2}$-stimulated duodenal bicarbonate secretion in the rat in vivo. American Journal of Physiology 255 G470-G475.

Howlett M, Judd LM, Jenkins B, La Gruta NL, Grail D, Ernst M \& Giraud AS 2005 Differential regulation of gastric tumor growth by cytokines that signal exclusively through the coreceptor gp130. Gastroenterology 129 1005-1018.

Inui A $1999 a$ Cancer anorexia-cachexia syndrome: are neuropeptides the key? Cancer Research 59 4493-4501.

Inui A $1999 b$ Feeding and body-weight regulation by hypothalamic neuropeptides-mediation of the actions of leptin. Trends in Neurosciences 22 62-67.

Itoh A, Nishihira J, Makita H, Miyamoto K, Yamaguchi E \& Nishimura M 2003 Effects of IL- $1 \beta$, TNF- $\alpha$, and macrophage migration inhibitory factor on prostacyclin synthesis in rat pulmonary artery smooth muscle cells. Respirology 8 467-472.

Jarkovska Z, Hodkova M, Sazamova M, Rosicka M, Dusilova-Sulkova S, Marek J, Justova V, Lacinova Z, Haluzik M, Haas T et al. 2005 Plasma levels of active and total ghrelin in renal failure: a relationship with GH/IGF-I axis. Growth Hormone and IGF Research 15 369-376.

Joppa MA, Ling N, Chen C, Gogas KR, Foster AC \& Markison S 2005 Central administration of peptide and small molecule MC4 receptor antagonists induce hyperphagia in mice and attenuate cytokine-induced anorexia. Peptides 26 2294-2301.

Kluger MJ \& Rothenburg BA 1979 Fever and reduced iron: their interaction as a host defense response to bacterial infection. Science 203 374-376.

Kojima M, Hosoda H, Matsuo H \& Kangawa K 2001 Ghrelin: discovery of the natural endogenous ligand for the growth hormone secretagogue receptor. Trends in Endocrinology and Metabolism 12 118-122.

Larkin M 1998 Thwarting the dwindling progression of cachexia. Lancet 3511336 
Lawrence CB \& Rothwell NJ 2001 Anorexic but not pyrogenic actions of interleukin-1 are modulated by central melanocortin-3/4 receptors in the rat. Journal of Neuroendocrinology 13 490-495.

Lundholm K, Daneryd P, Bosaeus I, Korner U \& Lindholm E 2004 Palliative nutritional intervention in addition to cyclooxygenase and erythropoietin treatment for patients with malignant disease: effects on survival, metabolism, and function. Cancer 100 1967-1977.

Luo JC, Shin VY, Yang YH, Wu WK, Ye YN, So WH, Chang FY \& Cho CH 2005 Tumor necrosis factor-alpha stimulates gastric epithelial cell proliferation. American Journal of Physiology. Gastrointestinal and Liver Physiology 288 G32-G38.

Markison S, Foster AC, Chen C, Brookhart GB, Hesse A, Hoare SR, Fleck BA, Brown BT \& Marks DL 2005 The regulation of feeding and metabolic rate and the prevention of murine cancer cachexia with a small-molecule melanocortin-4 receptor antagonist. Endocrinology $1462766-2773$.

Marks DL, Ling N \& Cone RD 2001 Role of the central melanocortin system in cachexia. Cancer Research 61 1432-1438.

Martin MJ, Jimenez MD \& Motilva V 2001 New issues about nitric oxide and its effects on the gastrointestinal tract. Current Pharmaceutical Design 7 881-908.

McCarthy DO 1999 Inhibitors of prostaglandin synthesis do not improve food intake or body weight of tumor-bearing rats. Research in Nursing and Health 22 380-387.

Murray MJ \& Murray AB 1979 Anorexia of infection as a mechanism of host defense. American Journal of Clinical Nutrition 32 593-596.

Omana-Zapata I \& Bley KR 2001 A stable prostacyclin analog enhances ectopic activity in rat sensory neurons following neuropathic injury. Brain Research 904 85-92.

Otero M, Nogueiras R, Lago F, Dieguez C, Gomez-Reino JJ \& Gualillo O 2004 Chronic inflammation modulates ghrelin levels in humans and rats. Rheumatology 43 306-310.

Plata-Salaman CR 1989 Immunomodulators and feeding regulation: a humoral link between the immune and nervous systems. Brain, Behavior, and Immunity 3 193-213.

Plata-Salaman CR 19991998 Curt P. Richter Award. Brain mechanisms in cytokine-induced anorexia. Psychoneuroendocrinology 24 25-41.

Ramos EJ, Suzuki S, Marks D, Inui A, Asakawa A \& Meguid MM 2004 Cancer anorexia-cachexia syndrome: cytokines and neuropeptides. Current Opinion in Clinical Nutrition and Metabolic Care 7 427-434.

Schepp W, Dehne K, Herrmuth H, Pfeffer K \& Prinz C 1998 Identification and functional importance of IL-1 receptors on rat parietal cells. American Journal of Physiology 275 G1094-G1105.
Shirota K, LeDuy L, Yuan SY \& Jothy S 1990 Interleukin-6 and its receptor are expressed in human intestinal epithelial cells. Virchows Archiv. B, Cell Pathology Including Molecular Pathology 58 303-308.

Tisdale MJ 1997 Biology of cachexia. Journal of National Cancer Institute 89 1763-1773.

Tschop M, Smiley DL \& Heiman ML 2000 Ghrelin induces adiposity in rodents. Nature 407 908-913.

Tschop M, Wawarta R, Riepl RL, Friedrich S, Bidlingmaier M, Landgraf R \& Folwaczny C 2001a Post-prandial decrease of circulating human ghrelin levels. Journal of Endocrinological Investigation 24 RC19-RC21.

Tschop M, Weyer C, Tataranni PA, Devanarayan V, Ravussin E \& Heiman ML $2001 b$ Circulating ghrelin levels are decreased in human obesity. Diabetes $\mathbf{5 0}$ 707-709.

Walch L \& Morris PL 2002 Cyclooxygenase 2 pathway mediates IL-1beta regulation of IL- $1 \alpha,-1 \beta$, and IL- 6 mRNA levels in Leydig cell progenitors. Endocrinology 143 3276-3283.

Wang L, Basa NR, Shaikh A, Luckey A, Heber D, St-Pierre DH \& Tache Y 2006 LPS inhibits fasted plasma ghrelin levels in rats: role of IL-1 and PGs and functional implications. American Journal of Physiology. Gastrointestinal and Liver Physiology 291 G611-G620.

Weinberg ED 1984 Iron withholding: a defense against infection and neoplasia. Physiological Reviews 64 65-102.

Wu R, Zhou M, Cui X, Simms HH \& Wang P 2003 Ghrelin clearance is reduced at the late stage of polymicrobial sepsis. International Journal of Molecular Medicine 12 777-781.

Wu R, Dong W, Zhou M, Cui X, Hank Simms H \& Wang P 2005 Ghrelin improves tissue perfusion in severe sepsis via downregulation of endothelin-1. Cardiovascular Research 68 318-326.

Yanni JM, Smith WL \& Foxwell MH 1988 U46619 and carbocyclic thromboxane A2-induced increases in tracheal mucous gel layer thickness. Prostaglandins, Leukotrienes, and Essential Fatty Acids 32 45-49.

\section{Received in final form 12 November 2007 \\ Accepted 19 November 2007 \\ Made available online as an Accepted Preprint 19 November 2007}

